\title{
PENGARUH MODEL PEMBELAJARAN PROBLEM BASED LEARNING TERHADAP PENINGKATAN KEMAMPUAN BERPIKIR KRITIS MATEMATIS SISWA SMP KELAS IX
}

\section{(THE INFLUENCE OF PROBLEM BASED LEARNING LEARNING MODELS ON THE IMPROVEMENT OF THE MATHEMATIC CRITICAL THINKING ABILITY OF CLASS IX JUNIOR HIGH SCHOOL STUDENTS)}

\author{
Nova Nadila Saputri Sitompul ${ }^{1}$ \\ ${ }^{1}$ FKIP Universitas Labuhanbatu, novanadila27@gmail.com
}

\begin{abstract}
Abstrak
Penelitian ini bertujuan untuk mengetahui pengaruh model pembelajaran problem based learning (PBL) terhadap peningkatan kemampuan berpikir kritis matematis siswa kelas IX di SMPN 4 Bilah Hulu. Jenis penelitian adalah eksperimen semu (quasi experiment). Model desain menggunakan pretest posttest kontrol group design. Populasi penelitian ini seluruh siswa SMP N 4 Bilah Hulu pada tahun ajaran 2020/2021 yang terdiri dari 156 siswa. Pengambilan sampel dilakukan menggunakan teknik random sampling dan diperoleh sampel penelitian yaitu IX-1 berjumlah 22 siswa sebagai kelas kontrol dan 22 siswa IX-2 sebagai kelas eksperimen. Instrument penelitian ini menggunakan tes dalam bentuk essay. Teknik analisis data menggunakan analisis deskriptif yang meliputi uji normalitas, uji homogenitas dan uji hipotesis yaitu uji-t (paired sample t-test). Hasil penelitian menunjukkan nilai sig. (2tailed) sebesar $0,000<0,05$, maka dapat disimpulkan siswa yang mendapatkan model pembelajaran problem based learning lebih baik dibandingkan dengan siswa yang menggunakan model pembelajaran konvensional.
\end{abstract}

Kata Kunci : Problem Based Learning, Berpikir Kritis

\begin{abstract}
This study aims to determine the effect of the problem based learning $(P B L)$ learning model on improving the mathematical critical thinking skills of grade IX students at SMPN 4 Bilah Hulu. This type of research is a quasi experiment. The design model used the pretest posttest control group design. The research population consisted of 156 students of SMP $N 4$ Bilah Hulu in the academic year 2020/2021. Sampling was done using random sampling technique and the research sample was obtained, namely IX-1 totaling 22 students as the control class and 22 students IX-2 as the experimental class. The research instrument used a test in the form of an essay. The data analysis technique used descriptive analysis which included normality test, homogeneity test and hypothesis test, namely the t-test (paired sample t-test). The results showed the sig. (2-tailed) of 0.000 $<0.05$, it can be concluded that students who get a problem based
\end{abstract}


learning model are better than students who use conventional learning models.

Keywords: Problem Based Learning, Critical Thinking

\section{PENDAHULUAN}

Pemerintah Indonesia juga paham akan arti pentingnya pendidikan untuk warga Negaranya. Semenjak berdirinya sebuah negara, maka pendidikan sudah terdaftar diantara salah satu tujuan utama pada bangsa ini ialah yang tercantum dalam kata mencerdaskan kehidupan bangsa. Hal ini bukanlah spontanitas keluar disaat Negara baru merdeka, justru pemerintah membangun komitmen yang ada didalam sebuah program wajib belajar agar semua Warga Negara Indonesia (WNI) serta berbagai sarana pada pendidikan semakin dikembangkan sehingga mampu meningkatkannya mutu pendidikan (Rahma \& Harahap, 2018).

Pendidikan berarti sekali, karena manusia jika tanpa pendidikan maka akan susah berkembang serta akan tertinggal. Pendidikan adalah salah satu upaya terhadap meningkatnya kualitas sumber energi manusia, bahkan fisik, mental, ataupun spiritual. Negara yang maju akan dapat terlihat dari rakyatnya yang memiliki tingkat ilmu pengetahuan. Banyaknya ilmu pengetahuan yang kuat kaitannya terhadap kemajuan bangsa serta dalam meningkatnya sumber daya manusia salah satu diantaranya adalah matematika (Nurlaeli et al., 2018). Peranan matematika benarbenar menentukan, oleh sebab itu guru harus dapat menjadikan matematika salah satu pelajaran yang mengasikkan dan disenangi oleh siswa serta mampu menunjang keberhasilan (Suriyani, 2017).

Panduan Kurikulum Tingkat Satuan Pendidikan (dalam Harahap, 2017) matematika adalah ilmu umum yang mendasari perkembangan teknologi modern, yang memiliki peranan penting dalam meningkatkan daya pikir orang. Pantas saja bila matematika jadi sebagai salah satu diantara mata pelajaran prasyarat untuk kelulusan sekolah mulai dari SD, SMP, serta SMA di Indonesia. Untuk dapat menguasai serta menciptakan teknologi di masa yang akan datang maka diperlukan penguasaan matematika dimulai sejak dini.

Mata pelajaran matematika butuh diberikan kepada seluruh siswa mulai dari SD untuk membekali siswa dengan keahlian berpikir logis, sistematis, analitis, kreatif, kritis serta keahlian dalam bekerja sama. Kompetensi tersebut dibutuhkan agar siswa mampu memiliki keahlian dalam menerima, mengelola, serta memanfaatkan informasi agar bertahan hidup dalam kondisi yang terus berubah, tidak tentu, serta kompetitif (Harahap, 2016).

Matematika merupakan satu dari beberapa mata pelajaran yang mampu dalam meningkatkan pendidikan karakter satu diantaranya melalui peningkatan hard skill peserta didik. Tipe hard skill matematis peserta didik diantara lainnya yaitu keahlian pemahaman matematis, keahlian penalaran matematis, keahlian pemecahan permasalahan matematis, keahlian komunikasi matematis, keahlian koneksi matematis, serta keahlian berpikir kritis matematis (Ratnawati et al., 2020). 
Dimulai sejak dini siswa harus mampu untuk mengembangkan kemampuan berpikir tingkat tinggi mereka. Sebab dengan mempunyai keahlian berpikir tingkat tinggi yang baik, siswa akan dengan mudah mendapatkan informasi baru serta menghubungkannya dengan informasi yang sudah dimilikinya. Kemudian, dengan mengolah informasi yang telah dimilikinya untuk dapat mengembangkan gagasangagasan baru dan memilah strategi penyelesaian yang sesuai untuk memecahkan permasalahan yang sekarang dihadapi. Ketika siswa sanggup menyelesaikan permasalahan dengan keahlian mereka sendiri, maka hal ini dapat berpengaruh positif terhadap penilaian diri (Munarsih \& Hasibuan, 2019).

Berdasarkan hasil wawancara dengan salah satu guru matematika di SMP N 4 Bilah Hulu diperoleh penjelasan bahwa perhatian masih terpusat pada guru sedangkan siswa hanya menerima pelajaran secara pasif. Sehinga saat proses pembelajaran berlangsung sedikit banyaknya siswa tidak memerhatikan guru menerangkan materi yang diajarkan, contohnya sibuk dengan kegiatannya dimeja, berbicara dengan teman sebangkunya, dan lain-lain. Namun guru tetap berusaha melakukan perbaikan dalam proses pembelajaran tetapi masih ada beberapa hal yang perlu ditindak lanjuti seperti kemampuan berpikir kritis siswa yang masih rendah.

Demikian pula hasil observasi awal yang dilakukan dengan siswa SMP N 4 Bilah Hulu $80 \%$ siswa mengalami masalah disaat proses pembelajaran berlangsung yaitu siswa hanya mencatat apa yang dijelaskan guru tanpa ada respon balik. Hasil menunjukkan terlihat dari rendahnya kemampuan berpikir kritis siswa melalui jawaban-jawaban dari soal matematika yang diberikan selama tiga kali berturut-turut. Dari 44 siswa kelas IX, 14 siswa (32\%) yang dapat memahami dan mengetahui pertanyaan permasalahan yang dimaksudkan dalam soal, 10 siswa (23\%) yang dapat menuliskan konsep yang digunakan dalam soal, 19 siswa (44\%) yang mampu menuliskan keterangan simbol dari model matematika yang telah di tentukan, 9 siswa (21\%) yang sanggup menyelesaikan soal menggunakan konsep dan model matematika yang telah ditentukan serta memberikan kesimpulan dari permasalahan, dan 9 siswa (21\%) yang dapat memberikan penjelasan lebih lanjut sesuai dengan permasalan dalam soal.Siswa juga masih merasa kesulitan ketika dihadapi dengan soal matematika yang baru.Ketika siswa diberikan soal matematika yang sedikit berbeda dengan contoh soal dari segi angka saja, siswa sudah kesulitan untuk menjawabnya karena mereka hanya mencatat rumus dan langkah-langkah menyelesaikan soalnya saja tetapi tidak dapat memahami konsepnya.Jika perhatian masih terpusat pada guru sedangkan siswa hanya menerima secara pasif maka materi yang di sampaikan oleh guru tidak akan diterima dengan baik oleh siswa.

(Yusri et al., 2018) menjelaskan untuk mengatasi permasalahan tersebut yang dapat diterapkan seorang guru adalah dengan menggunakan suatu strategi pendidikan yang lebih bervariasi. Diantara banyaknya alternatif yang bisa jadi opsi guru pada proses pendidikan salah satunya merupakan efektivitas pemakaian model pembelajaran. Model pembelajaran yang bisa meningkatkan keahlian pemecahan kasus matematika siswa salah satunya ialah pembelajaran menggunakan model problem based learning (PBL). Berdasarkan uraian tersebut, penelitian yang dilakukan ini bertujuan untuk dapat mengetahui pengaruh model pembelajaran problem based learning (PBL) terhadap peningkatan kemampuan berpikir kritis 
matematis siswa SMP kelas IX. Serta, manfaat yang dapat diambil dari penelitian ini adalah agar model pembelajaran problem based learning ini dapat digunakan guru untuk referensi dalam peningkatan kemampuan berpikir kritis matematis siswa SMP.

\section{KAJIAN TEORI}

\section{Model Pembelajaran Problem Based Learning (PBL)}

Dalam model pembelajaran Problem Based Learning (PBL), fokus pendidikan terdapat pada permasalahan yang diseleksi sehingga siswa bukan hanya mempelajari konsep yang berkaitan dengan permasalahan namun juga metode ilmiah dalam memecahkan permasalahan tersebut. Oleh karena itu, siswa tidak hanya wajib menguasai konsep yang relevan pada permasalahan yang jadi pusat perhatian namun juga mendapatkan pengalaman studi yang berkaitan dengan keahlian mengaplikasikan metode ilmiah pada pemecahan permasalahan serta meningkatkan acuan berpikir kritis.Problem Based Learning (PBL) ialah satu diantara banyaknya model pembelajaran yang dapat meningkatkan keahlian berpikir kritis siswa (Sianturi et al., 2018).

Menurut pendapat Wirkala \& Kuhn (Prihono \& Khasanah, 2020) Pembelajaran berbasis permasalahan adalah metode pengajaran serta pembelajaran yang dimana siswa ikut serta dalam permasalahan tanpa riset persiapan serta dengan pengetahuan seperlunya untuk memecahkan permasalahan, mengharuskan siswa untuk memperluas pemahaman dan wawasan yang ada serta mengaplikasikan peningkatan wawasan ini untuk menciptakan solusi. Sedangkan pendapat Arends (dalam Nurlaeli et al., 2018) menyatakan kalau model PBL adalah model pembelajaran dengan menggunakan pendekatan pembelajaran dalam permasalahan yang autentik supaya siswa bisa merancang pengetahuannya sendiri, meningkatkan inkuiri, serta keahlian berpikir tingkatan tinggi, dan meningkatkan kemandirian serta keyakinan diri.

Langkah pembelajaran dengan menggunakan model Problem Based Learning terbentuk dari: (1) Orientasi siswa terhadap permasalahan; (2) Mengelompokkan siswa dalam belajar; (3) Menolong aktivitas penyelidikan individu serta kelompok; (4) Meningkatkan dan menyampaikan hasil karya; dan (5) Menganalisa serta mengevaluasi hasil pemecahan permasalahan (Arifin et al., 2015). Model PBL memberikan kesempatan terhadap siswa untuk dapat lebih aktif saat berdiskusi dalam kelompok dan dapat memecahkan suatu permasalahan yang dirasakan secara kolaboratif.Model PBL memiliki sebagian kelebihan agar dapat digunakan dalam meningkatkan kemampuan berpikir kritis. Model PBL memberikan suasana belajar yang lebih menantang untuk siswa supaya dapat menghasilkan pengetahuan baru. Kemudian, model pembelajaran ini juga membantu siswa dalam mengembangkan pemahaman baru yang telah dicapai dikehidupan nyata. Bukan cuma itu, model problem based learning juga bisa meningkatkan siswa untuk lebih berpikir kritis dan bisa memberikan kesempatan pada siswa untuk dapat mengaplikasikan pemahaman yang mereka punya didalam kehidupan sehari-hari (Sukmawati, 2020).

Kelebihan model Problem Based Learning (PBL) yaitu (1) siswa didorong agar mempunyai kemampuan memecahkan suatu masalah pada situasi nyata; (2) siswa mempunyai kemampuan membangun pemahamannya sendiri melalui kegiatan 
belajar; (3) pembelajaran berpusat pada permasalahan sehingga materi yang tidak terdapat kaitannya tidak butuh dipelajari siswa dengan menghafal ataupun menyimpan informasi; (4) terjadi kegiatan ilmiah terhadap siswa dengan melalui kerja kelompok; (5) siswa terbiasa memakai sumber pengetahuan baik melalui internet, observasi, wawancara, dan perpustakaan; (6) siswa mempunyai kemampuan dalam menilai kemajuan belajar mereka sendiri; (7) siswa mempunyai kemampuan guna melaksanakan komunikasi ilmiah pada kegiatan diskusi ataupun presentasi hasil dari pekerjaan mereka; dan (8) kesusahan belajar siswa secara individu bisa diatasi lewat kerja kelompok pada bentuk peer teaching. Adapun kelemahan model problem based learning (PBL) yaitu (1) PBL tidak bisa diterapkan disetiap materi pelajaran, terdapat sebagian guru berperan aktif saat menyajikan materi. PBL lebih sesuai pada pembelajaran yang menekan kemampuan tertentu yang ada hubungannya dengan memecahkan masalah; (2) pada suatu kelas yang mempunyai tingkat keanekaragaman siswa yang besar akan terjadi kesusahan saat pembagian tugas (Shoimin, 2016).

\section{Berpikir Kritis Matematis}

Heris \& Utari (dalam Prihono \& Khasanah, 2020) menyatakan berpikir kritis bagaikan upaya menuangkan tanggapan secara reflektif serta beralasan yang dipusatkan dalam pengesahan keputusan yang sudah dipercayai serta dicoba. Maka berpikir kritis ialah proses terstruktur pada diri yang membolehkan siswa melaksanakan analisa, penilaian fakta serta bahasa yang melandasi statment orang lain. Sedangkan menurut Fachrurazi (dalam Umam, 2018) berpikir kritis bisa dikatakan seperti bentuk kegiatan mental ataupun pemikiran manusia yang aktif. Berpikir kritis pada matematika merupakan berpikir yang mengetes, mempersoalkan, menghubungkan, serta mengevaluasi seluruh aspek yang terdapat dalam suasana apapun pada suatu masalah.

AACU (dalam Syutharidho \& M, 2015) menjelaskan bahwa berpikir kritis merupakan kebiasaan berpikir yang diisyaratkan dengan semangat dalam mendapatkan pelajaran lebih banyak ataupun berupaya untuk menangkap pelajaran dengan baik saat mengutarakan pendapat ataupun kesimpulan.

Banyak manfaat yang akan diperoleh oleh siswa dari kemampuan berpikir kritis matematis, antara lain bisa meningkatkan serta mengembangkan pemahaman terhadap konsep dan bisa meningkatkan kemampuan berpikirnya maka akan lebih memudahkan siswa dalam memecahkan soal yang lebih kompleks. Tetapi realitas yang berlangsung dilapangan malah kebalikannya dari perkembangan keahlian berpikir kritis matematis siswa masih saja belum sesuai dengan apa yang dinginkan (Ratnawati et al., 2020).

Keahlian berpikir kritis mengasah siswa guna membuat gagasan serta keputusan dari bermacam sudut pandang sebagai perinci, teliti, cermat, serta logis.Siswa yang mempunyai keahlian berpikir kritis dalam matematis yang bagus bisa membuat gagasan serta representasi yang bermacam- macam. Perihal ini hendak lebih mempermudah siswa buat menciptakan serta memastikan alternatif penyelesaian sesuatu kasus yang berdampak meningkatnya keahlian berpikir kritis ketika menuntaskan kasus matematis maupun kasus tiap hari (Prihono \& Khasanah, 2020). 
Berpikir kritis pada pendidikan bertujuan buat memusatkan siswa agar mempunyai metode berpikir yang tersusun serta pintar dalam menstrukturkan antar konsep buat membongkar permasalahan. Informasi riset pendahuluan menampilkan bahwa tidak sedikit peserta didik yang kurang piawai membongkar permasalahan serta menciptakan alternatif penyelesaian yang bermacam- macam (Umam, 2018).

Kemampuan berpikir kritis yang dikembangkan oleh (Paradesa, 2017) terdapat lima indikator yangmerupakan : (1) kemampuan menggeneralisasi, ialah kemampuan siswa dalam memahami apa yang mereka ketahui terhadap permasalahan serta mengetahui apa yang dipertanyakan dalam setiap permasalahan yang diberikan, (2) kemampuan mengidentifikasi, ialah kemampuan setiap siswa dalam menuliskan konsep yang akan digunakan dari permasalahan yang diberikan, (3) kemampuan merumuskan permasalahan kedalam model matematika, ialah kemampuan setiap siswa dalam menuliskan penjelasan simbol pada model matematika yang sudah ditetapkan, (4) kemampuan mendeduksi dalam menggunakan prinsip, ialah kemampuan siswa dalam menyelesaikan masalah yang sudah diberikan dengan memakai konsep serta model matematika yang sudah ditetapkan dan sanggup memberi kesimpulan terhadap permasalahan tersebut, (5) kemampuan memberikan keterangan lanjut, ialah kemampuan siswa saat memberikan keterangan lebih lanjut yang cocok dengan masalah yang diberikan.

\section{METODE}

Metode yang digunakan dalam penelitian ini merupakan jenis penelitian eksperimen semu (quasi experiment).Variabel dalam penelitian ini terdiri dari variabel bebas dan variabel terikat. Variabel bebas pada penelitian ini yaitu model Problem Based Learning (X) dan variabel terikat pada penelitian ini adalah kemampuan berpikir kritis matematis siswa (Y).

Populasi dalam penelitian ini adalah seluruh siswa SMP N 4 Bilah Hulu pada tahun ajaran 2020/2021 yang terdiri dari 156 siswa. Pengambilan sampel dilakukan dengan menggunakan teknik random sampling dan diperoleh sampel penelitian yaitu IX-1 berjumlah 22 siswa sebagai kelas kontrol dan 22 siswa IX-2 sebagai kelas eksperimen.

Model desain yang digunakan dalam penelitian ini adalah model pretest posttest control group design, dimana dua kelas sampel diberikan perlakuan yang berbeda. Adapun desain yang digunakan digambarkan sebagai berikut :

Tabel 1. Pretest Posttest Control Group Design

\begin{tabular}{cccc}
\hline Kelas & $\begin{array}{c}\text { Tes Awal (Pre- } \\
\text { test) }\end{array}$ & Perlakuan & $\begin{array}{c}\text { Tes Akhir (Pos- } \\
\text { test) }\end{array}$ \\
\hline Eksperimen & $\mathrm{X}_{1}$ & $\begin{array}{c}\text { Problem Based } \\
\text { learning }\end{array}$ & $\mathrm{X}_{2}$
\end{tabular}




\begin{tabular}{cccc} 
Control & $\mathrm{X}_{1}$ & Konvensional & $\mathrm{X}_{2}$ \\
\hline
\end{tabular}

Keterangan :

$\mathrm{X}_{1}$ : Tes kemampuan sebelum diberikan model pembelajaran problem based learning $\mathrm{X}_{2}$ : Tes kemampuan setelah diberikan model pembelajaran problem based learning

Data yang digunakan dalam penelitian ini dikumpulkan menggunakan instrument tes dalam bentuk essay. Lembar tes soal essay digunakan untuk mengukur kemampuan berpikir kritis matematis sebelum dan sesudah dilakukanpembelajaran pada kedua kelas, lembar tes soal dalam penelitian ini terdiri dari 5 soal essay. Lembar tes essay telah melewati tahapan validasi oleh para ahli serta telah diuji validitas dan reliabilitasnya. Selanjutnya, teknik analisis data dalam penelitian ini ialah analisis deskriptif yang meliputi uji normalitas, uji homogenitas dan uji hipotesis. Uji statistik yang dipakai untuk uji hipotesis yaitu uji-t (paired sample $t$ test)untuk mengetahui apakah model pembelajaran problem based learning (PBL) berpengaruh terhadap peningkatan kemampuan berpikir kritis matematis siswa.

\section{HASIL DAN PEMBAHASAN}

Data hasil penelitian ini diperoleh dari nilai pre-test dan post-test yang menunjukkan adanya peningkatan kemampuan berpikir kritis matematis siswa.Data tersebut akan dianalisis dengan menggunakan uji normalitas, uji homogenitas dan uji hipotesis, adapun data hasil mengenai pre-test dan post-test kemampuan berpikir kritis matematis siswa dari masing-masing kelas bisa dilihat dari tabel berikut :

Tabel 2. Statistik Deskriptif Data Pre-Test Dan Post-Test

\begin{tabular}{lccccc}
\hline & N & Minimum & Maximum & Mean & $\begin{array}{c}\text { Std. } \\
\text { Deviation }\end{array}$ \\
\hline Pre-Test Eksperimen & 22 & 55 & 75 & 65.27 & 6.685 \\
Post-Test Eksperimen & 22 & 80 & 95 & 87.41 & 4.102 \\
Pre-Test Kontrol & 22 & 55 & 75 & 62.73 & 6.096 \\
Post-Test Kontrol & 22 & 60 & 75 & 67.91 & 4.975 \\
Valid N (listwise) & 22 & & & & \\
\hline
\end{tabular}

Berdasarkan tabel di atas, dapat dilihat hasil dari analisis bahwa pre-test kelas eksperimen dan kontrol nilai minimumnya 55 dan maksimalnya 75. Analisis dari hasil post-test kelas eksperimen nilai minimumnya 80 dan maksimalnya 95.Sedangkan, hasil dari post-test kelas kontrol nilai minimumnya 60 dan maksimalnya 75 .

\section{Uji Normalitas}

Uji normalitas dilakukan untuk mengetahuiapakah data penelitian berdistribusi normal. 
Table 3. Uji Normalitas Kolmogorov Smirnov

\begin{tabular}{llccc}
\hline & \multicolumn{1}{c}{ Kelas } & \multicolumn{3}{c}{ Kolmogorov-Smirnov $^{\mathrm{a}}$} \\
\cline { 3 - 5 } & Statistic & $\mathrm{df}$ & Sig. \\
\hline & $\begin{array}{l}\text { Pre-Test Eksperimen } \\
\text { (PBL) }\end{array}$ & .166 & 22 & .120 \\
Berpikir Kritis & $\begin{array}{l}\text { Post-Test Eksperimen } \\
\text { (PBL) }\end{array}$ & .148 & 22 & $.200^{*}$ \\
Matematis Siswa & $\begin{array}{l}\text { Pre-Test Kontrol } \\
\text { (Konvensional) }\end{array}$ & .145 & 22 & $.200^{*}$ \\
& $\begin{array}{l}\text { Post-Test Kontrol } \\
\text { (Konvensional) }\end{array}$ & .130 & 22 & $.200^{*}$ \\
\hline
\end{tabular}

Berdasarkan tabel diatas, menunjukkan nilai sig. pre-test kelas eksperimen $0,120>0,05$ dan nilai sig. post-test kelas eksperimen $0,200>0,05$. Begitu juga dengan nilai sig. pre-test dan post-test kelas kontrol 0,200>0,05 maka $\mathrm{H}_{\mathrm{o}}$ diterima. Kesimpulannya pre-test dan post-test pada kelas eksperimen dan kelas kontrol berdistribusi normal. Karena data penelitian berdistribusi normal, maka selanjutnya kita dapat mengunakan uji homogenitas dengan menggunakan uji Levene Statistic dengan bantuan Software SPSS 20 untuk mengetahui data yang diperoleh homogen atau tidak.

\section{Uji Homogenitas}

Uji homogenitas dalam penelitian ini bertujuan untuk mengetahui apakah varians data post-test kelas eksperimen (PBL) dan data post-test kelas kontrol (Konvensional) bersifat homogen atau tidak.

Table 4. Uji Homogenitas

\begin{tabular}{cccc}
\hline Levene Statistic & df1 & df2 & Sig. \\
\hline 1.360 & 1 & 42 & .250 \\
\hline
\end{tabular}

Berdasarkan tablet diatas, diketahui nilai sig. $0,250>0,05$. Sehingga dapat disimpulkan bahwa varians data post-test kelas eksperimen dan data post-test kelas kontrol adalah homogen atau sama. Selanjutnya, uji hipotesis dengan mengunakan uji-t (paired sample t-test).

\section{Uji Paired Sample T-Test}

Uji paired sample t-test digunakan untuk mengetahui apakah terdapat perbedaan rata-rata dua sample yang berpasangan. Dalam penelitian ini uji paired sample t-test untuk menjawab dari rumusan masalah yaitu apakah model pembelajaran problem based learning berpengaruh terhadap peningkatan kemampuan berpikir kritis matematis siswa SMP kelas IX. 
Tabel 5. Uji Paired Sample T-Test

\begin{tabular}{lcccc}
\hline & Std. Deviation & T & df & Sig. (2-tailed) \\
\hline $\begin{array}{l}\text { PreTest Eksperimen - } \\
\text { PostTest Eksperimen }\end{array}$ & 6.756 & -15.368 & 21 & .000 \\
\hline
\end{tabular}

Berdasarkan table diatas, diperoleh nilai sig. (2-tailed) sebesar 0,000 $<0,05$, maka dapat disimpulkan ada perbedaan rata-rata berpikir kritis matematis siswa SMP kelas IX di Bilah Hulu dengan siswa yang mendapatkan model pembelajaran problem based learning lebih baik dibandingkan dengan siswa yang menggunakan model pembelajaran konvensional.

\section{SIMPULAN DAN SARAN}

Berdasarkan hasil penelitian dari pembahasan diatas maka dapat diperoleh nilai sig. (2-tailed) sebesar $0,000<0,05$, maka ada perbedaan rata-rata berpikir kritis matematis siswa SMP kelas IX di Bilah Hulu. Kesimpulan bahwa hasil menunjukkan terdapat pengaruh yang signifikan model problem based learning terhadap peningkatan kemampuan berpikir kritis matematis siswa kelas IX SMPN 4 Bilah Hulu.

Saran dari penelitian ini yaitu untuk para pendidik agar lebih memerhatikan hal-hal dalam pembelajaran khususnya matematika seperti materi yang mudah untuk dipahami oleh siswa, metode pembelajaran serta starteginya agar dapat menarik perhatian siswa dan disenangi. Di dalam pembelajaran guru juga harus dapat mengikut sertakan siswa agar pembelajaran tidak hanya terpusat pada guru sedangkan siswa hanya menerima pelajaran secara pasif. Peneliti juga memberikan saran kepada peneliti selanjutnya untuk dapat menerapkan model pembelajaran problem based learning untuk meningkatkan kemampuan berpikir kreatif matematis siswa.

\section{DAFTAR PUSTAKA}

Arifin, Hudiono, B., \& Suratman, D. (2015). Pengaruh problem based learning terhadap kemampuan berpikir kritis matematis pada materi gradien di smp. Jurnal Pendidikan Dan Pembelajaran, 4(3), 1-15.

HRP, Nurlina, A. (2016). Keefektifan Model Pembelajaran Kooperatif Dengan Metode Penemuan Berbantuan Lembar Kerja Siswa (Lks) Pada Pembelajaran Matematika Sub Materi Pokok Trigonometri Kelas X Sma Negeri 8 Semarang Semester 2 Tahun Pelajaran 2006/2007. Jurnal Pembelajaran Dan Matematika Sigma (JPMS), 2(1), 40-46.

HRP, Nurlina, A. (2017). Peningkatan Kemampuan Representasi Matematis Dan Motivasi Belajar Siswa Melalui Model Pembelajaran Berbasis Proyek (Project Based Learning) Di Kelas VII SMP Negeri 1 Torgamba Tahun Pelajaran 2016/2017. Jurnal Pembelajaran Dan Matematika Sigma (JPMS), 3(1), 38-48.

Munarsih, S., \& Hasibuan, L. R. (2019). Pengaruh Pendekatan Open Ended Problems terhadap Kemampuan Berpikir Kreatif The Effect of Open Ended Problems Approach on Students , Creative Mathematical Thinking Ability on 
Opportunities in Class XI of SMA Negeri 1 Rantau Utara. Jurnal Pembelajaran Dan Matematika Sigma (JPMS), 5(1), 21-29.

Nurlaeli, Noornia, A., \& Wiraningsih, E. D. (2018). Pengaruh model pembelajaran problem based learning terhadap kemampuan berpikir kritis matematis siswa ditinjau dari adversity quotient 1,2,3). FIBONACCI: Jurnal Pendidikan Matematika Dan Matematika, 4(2), 145-154.

Paradesa, R. (2017). Kemampuan berpikir kritis matematis mahasiswa melalui pendekatan konstruktivisme pada matakuliah matematika keuangan. Jurnal Pendidikan Matematika RAFA, 1(2), 306-325.

Prihono, E. W., \& Khasanah, F. (2020). Pengaruh Model Problem Based Learning Terhadap Kemampuan Berpikir Kritis Matematis Siswa Kelas Viii Smp. EDUMAT: Jurnal Pendidikan Matematika, 8(1), 74-87. https://doi.org/10.20527/edumat.v8i1.7078

Rahma, I. F., \& Hrp, N. A. (2018). Behavior Modification Dan Metode Guided Discovery Pada. Jurnal Pembelajaran Dan Matematika Sigma (JPMS) , 4(1), 44-47.

Ratnawati, D., Handayani, I., \& Hadi, W. (2020). Pengaruh Model Pembelajaran Pbl Berbantu Question Card Terhadap Kemampuan Berpikir Kritis Matematis Siswa Smp. Edumatica: Jurnal Pendidikan Matematika, 10(01), 44-51. https://doi.org/10.22437/edumatica.v10i01.7683

Shoimin, A. (2016). 68 Model Pembelajaran Inovatif dalam Kurikulum 2013. Yogyakarta: Ar-Ruzz Media.

Sianturi, A., Sipayung, T. N., \& Simorangkir, F. M. A. (2018). Pengaruh Model Problem Based Learning (PBL) Terhadap Kemampuan Berpikir Kritis Matematis Siswa SMPN 5 Sumbul. UNION: Jurnal Ilmiah Pendidikan Matematika, 6(1), 29-42. https://doi.org/10.30738/.v6i1.2082

Sukmawati, A. (2020). Meta Analisis Model Problem Based Learning Dalam Meningkatkan Kemampuan Berpikir Kritis Pada Pembelajaran Matematika. Thinking Skills and Creativity Journal, 3(2), 63-68.

Suriyani. (2017). Pengaruh Model Reciprocal Teaching Terhadap Kemampuan Berpikir Kreatif Matematika Siswa Di Mts Roudhotul. Jurnal Pembelajaran Dan Matematika Sigma (JPMS), 3(1), 65-70.

Syutharidho, \& M, rosida rakhmawati. (2015). Pengembangan Soal Berpikir Kritis untuk Siswa SMP Kelas VIII Syutharidho, Rosida Rakhmawati M 1. Al-Jabar: Jurnal Pendidikan Matematika, 6(2), 219-227.

Umam, K. (2018). Peningkatan Kemampuan Berpikir Kritis Matematis Siswa Melalui Pembelajaran Reciprocal Teaching. JPMI (Jurnal Pendidikan Matematika Indonesia), 3(2), 57. https://doi.org/10.26737/jpmi.v3i2.807

Yusri, A. Y., Matematika, P., Andi, S., \& Pangkep, M. (2018). Pengaruh Model Pembelajaran Problem Based Learning Terhadap Kemampuan Pemecahan Masalah Matematika. Mosharafa, 7, 51-62. 